\title{
Prikazi
}

https://doi.org/10.22210/suvlin.2020.089.06

\section{Prva slovačka kontrastivna sintaksa (u usporedbi s hrvatskom). Dubravka Sesar, Pregled slovačke sintakse, Filozofski fakultet Sveučilišta u Zagrebu, FF press, 2018., 158 str.}

Pregled slovačke sintakse Dubravke Sesar objavljen je u prestižnom nizu Manualia Universitatis studiorum Zagrabiensis. Riječ je o sveučilišnom udžbeniku namijenjenom studiju slovačkoga jezika i književnosti, koji je kao jedan od neofiloloških studija na Filozofskom Fakultetu u Zagrebu pokrenut 1997./98. akademske godine zahvaljujući upravo autorici udžbenika.

Knjiga je napisana na hrvatskom jeziku, a naslovi, poglavlja i potpoglavlja napisani su dvojezično (hrvatski i slovački). Dvojezičnost se dosljedno zadržava u primjerima koji ilustriraju pojedine sintaktičke pojave i kategorije. Takav se autoričin postupak pokazuje vrlo korisnim jer u postojećim hrvatsko-slovačkim rječnicima nije na zadovoljavajući način obrađeno ni osnovno gramatičko pojmovlje.

Autorica je svoju preglednu sintaksu slovačkoga jezika koncipirala polazeći ponajprije od vlastita nastavnoga iskustva sa studentima zagrebačke slovakistike. Zato u njoj skreće pozornost na one točke koje se u sintaksama hrvatskoga jezika obrađuju drukčije nego u sintaksama slovačkoga jezika, ili se tumače s pomoću drukčijih gramatičkih, semantičkih ili funkcionalnih kriterija pa u studenata često izazivaju nesporazume, kao što sama ističe u svojem predgovoru. Riječ je, dakle, o prvoj kontrastivnoj slovačkoj sintaksi u usporedbi s hrvatskom (poput Wójcikove ruske kontrastivne gramatike na poljskoj osnovi, Varšava 1973, ili ruske sintakse u usporedbi s češkom, red. M. Kubík, Prag 1982).

Knjiga se sastoji od Predgovora (str. 7), teoretskoga dijela podijeljenoga na 16 poglavlja s nizom potpoglavlja (str. 9-98), dodatka koji sadrži praktični dio (str. 101-127), obosmjernoga kazala pojmova (Hrvatsko-slovačko kazalo pojmova (str. 141-148) i Slovačko-hrvatsko kazalo pojmova (str. 149-156)) te popisa literature (str. 157-158).

U teoretskom dijelu u prvim je trima poglavljima definirano osnovno sintaktičko pojmovlje (sintaksa, rečenica i rečenični članovi, sintagma i dr.). Zatim slijede poglavlja posvećena jednostavnoj rečenici, u kojima autorica komparativnom metodom opisuje pojedinačne glavne (subjekt i predikat) i dodatne rečenične članove (objekt, atribut, apoziciju, predikatni atribut - proširak i priložnu oznaku). U dodatne članove svrstava i apoziciju (slov. prístavok) i predikatni atribut - proširak (slov. doplnok), uz napomenu da su te dvije pojave u slovačkim gramatikama svrstane u polurečenične ili polupredikatne strukture - polopredikatívne (polovetné) konštrukcie. One se opisuju odmah u sljedećem kratkom, no komparativnim zapa- 
žanjima bogatom poglavlju. U njemu autorica upozorava na različite nazive analognih jezičnih pojava u slovačkome i hrvatskome, na različite sustave participa u sintaksama obaju jezika kao i na daleko veću mogućnost adjektivizacije aktivnih participa sadašnjih (činné príčastie prítomné) u slovačkome nego u hrvatskome. Koncepcija Pregleda predstavlja sintaksu u užem smislu, no ipak, prije opisa sintaktičke strukture složene rečenice i rečeničnih odnosa autorica u obradu uključuje i nekoliko poglavlja o sintaktičkim pojavama koje ulaze u domenu sintakse teksta. To su poglavlja o modalnosti i emocionalnosti, o obavijesnom ustrojstvu iskaza i sintaktičkim specifičnostima u tekstu (npr. parenteza, istaknuti i izolirani rečenični član, elipsa, ponavljanje itd.). Modalnost definira kao sintaktičko-semantičku kategoriju, za razliku od izvanjezične (psihološke) kategorije emocionalnosti, te navodi konstitutivna i fakultativna jezična sredstva za njezino iskazivanje s obzirom na strukturne i značenjske karakteristike iskaza (postojová, istotná, voluntatívna modálnost' - osnovna m., m. vjerodostojnosti, voluntativna m.). Poglavlje o semantičkom ili obavijesnom ustrojstvu iskaza, koje se u slovačkim sintaksama tradicionalno naziva aktualnom raščlambom (aktuálne členenie výpovede), dopunjava i opisom osnovnih obavijesnih, zvukovnih te gramatičkih čimbenika koji utječu na red riječi. Zatim slijede poglavlja posvećena sintaktičkoj strukturi složene rečenice. Autorica razmatra složene rečenice u determinativnom (zavisnosložene) i koordinacijskom odnosu (nezavisnosložene) kao i višestruko složene rečenice u slovačkome u usporedbi s hrvatskim. Teoretski dio završava kratkim poglavljima o sintaksi teksta i o interpunkciji.

Tumačenje teorije potkrijepljeno je brojnim primjerima, koji su uglavnom, kako sama autorica navodi, ekscerpirani iz slovačkih gramatika. Ponegdje su skraćeni ili neznatno modificirani kako bi bili jednostavniji i jasniji hrvatskim studentima te usporediviji s istim ili sličnim pojavama u hrvatskom jeziku. Uza sve slovačke primjere navode se i njihovi hrvatski ekvivalenti (prijevodi). U slučajevima nepostojanja ekvivalentnih sintaktičkih struktura između slovačkoga i hrvatskoga, navode se strukturno drugačiji ekvivalenti, vidljivi i naglašeni grafički (npr. u zagradama) te uz popratni komentar. Nakon teorijskoga dijela dolaze tekstovi i vježbe, tj. praktični dio, u kojem studenti imaju mogućnost primijeniti svoje teorijsko znanje. Sintaktičke vježbe temelje se na izabranim slovačkim književnim tekstovima prikladnim za sintaktičku analizu. Za samoprovjeru studentima odlično služe i navedena rješenja vježbi.

Pri obradi sintaktičke građe autorica se oslanja prije svega na klasičnu relevantnu slovačku literaturu (npr. radove J. Mistríka, E. Paulinyja, J. Oravca i E. Bajzíkové) kao i na najnovija djela iz oblasti suvremene slovačke sintakse (npr. Ivanová 2011; Kačala 2012, 2013; Pavlović 2012). Tumačenje slovačkih sintaktičkih struktura i jezičnih pojava uspoređuje s hrvatskim opisima analognih sintaktičkih pojava (Katičić, Pranjković i dr.), pri čemu je vidljiva i široka upućenost autorice u sintaktičke spoznaje i sintakse drugih slavenskih jezika (o tome svjedoče i njezini brojni sintaktički radovi). 
Od posebne je vrijednosti to što autorica korisnike svojega udžbenika kroz cijeli teoretski dio upozorava na problematična sintaktička pitanja na koja jezikoslovci nemaju ujednačenih odgovora (npr. definiranje i određivanje apozicije: u slovačkome pekár Jozef pečie chlieb, u hrvatskome pekar Josip peče kruh, usp. str. 36-37), razlike u uporabi analognih sintaktičkih pojava (npr. ne/sročnost imenskoga dijela predikata s rodom osobe kojoj se obraćamo u oslovljavanju na $V i$, str. 25; veća učestalost imenskoga dijela predikata u instrumentalu u slovačkome, str. 26; razlike u završnoj intonaciji tzv. totalnih pitanja vezane uz uporabu hrvatske upitne čestice $l i$ kao i slovačkoga pitanja u niječnom obliku, str. 50) kao i na neekvivalentnost određenih sintaktičkih pojava između hrvatskoga i slovačkoga jezika odnosno njihovo nepostojanje u jednome od dvaju uspoređenih jezika (npr. infinitiv uz pomoćne limitativne glagole u slovačkome, str. 22; slovačka (gramatička) i hrvatska (logička) interpunkcija u zavisnosloženim rečenicama, str. 73; slovački predikatni atributi s infinitivom, str. 40 i 78). Uspoređujući slovački jezik s hrvatskim, otvara pitanja važna i samo za hrvatsko jezikoslovlje, kao što je to npr. u slučaju hrv. čestice zar u niječnim upitnim iskazima (str. 54) ili već spomenuto određivanje apozicije.

Važnim doprinosom može se smatrati terminološko kazalo (hrvatsko-slovačko i slovačko-hrvatsko kazalo) jer osim njega ne postoji hrvatsko-slovački prijevod jezikoslovnih naziva, pri čemu popis termina obuhvaća ne samo područje sintakse, nego i drugih jezičnih razina (npr. pravopis, morfologija).

Hrvatski jezik na kojem je napisan udžbenik samo je jedan od čimbenika koji olakšava studentima bolje i brže usvajanje sintakse slovačkoga jezika. Ipak, jedan od najvažnijih čimbenika upravo je hrvatska perspektiva iz koje autorica piše, jer otkriva i tumači specifične probleme s kojima se studenti kao govornici hrvatskoga jezika mogu susresti pri učenju sintaktičkih struktura u slovačkom jeziku. Zahvaljujući pristupačnosti autoričina jezika i stila kao i prilagođenosti cjelovite koncepcije udžbenika studentskim jezičnim predznanjima i potrebama s jedne strane, a s druge strane zahvaljujući preglednosti i tumačenju sintaktičkih pitanja s distanciranim pogledom na sintaktičku građu kojom savršeno vlada u oba jezika, nastao je udžbenik iz kojega se želi učiti. Iako je Pregled slovačke sintakse namijenjen prije svega hrvatskim studentima slovačkoga jezika, mogu ga sigurno dobro iskoristiti i slovački studenti koji studiraju hrvatski jezik, jer se i njima otkrivaju sintaktičke razlike između ta dva srodna jezika. Osim toga, odgovori na pitanja ekvivalentnosti ili neekvivalentnosti određenih sintaktičkih struktura jako su potrebna i prevoditeljima. Komparacija slovačke sintakse s hrvatskom obogaćena novim spoznajama i suvremenim sintaktičkim pristupom i u širem slavističkom kontekstu čini ovo djelo važnim doprinosom ne samo za slovakistiku, nego i za kroatistiku te komparativnu lingvistiku uopće, a posebno za slavenske jezike.

Martina Grčević 